\title{
Primary effusion lymphoma
}

INSERM

\section{Source}

INSERM. (1999). Orphanet: an online rare disease and orphan drug data base. Primary effusion lymphoma. ORPHA:48686

Primary effusion lymphoma (PEL) is a large B-cell lymphoma located in the body cavities, characterized by pleural, peritoneal, and pericardial fluid lymphomatous effusions and that is always associated with human herpes virus-8 (H HV-8). 